\title{
$17 \beta$-Estradiol inhibits proliferation and migration of human vascular smooth muscle cells: similar effects in cells from postmenopausal females and in males
}

\author{
Do Dai-Do ${ }^{c}$, Emma Espinosa ${ }^{\text {a,1 }}$, Guizhen Liu ${ }^{a}$, Ton J. Rabelink ${ }^{a, 2}$, Friedgard Julmy ${ }^{\text {a }}$, \\ Zhihong Yang ${ }^{a}$, Felix Mahler ${ }^{c}$, Thomas F. Lüscher ${ }^{\mathrm{a}, \mathrm{b}, *}$ \\ a Department of Cardiovascular Research, University Hospital, 3010 Bern, Switzerland \\ ${ }^{\mathrm{b}}$ Department of Cardiology, University Hospital, Bern, Switzerland \\ ${ }^{\mathrm{c}}$ Department of Angiology, University Hospital, Bern, Switzerland
}

Received 16 February 1996; accepted 24 May 1996

\begin{abstract}
Objectives: Cardiovascular disease is rare in premenopausal women, but increases after the menopause when hormone replacement therapy reduces coronary events. Vascular smooth muscle cell (SMC) proliferation and migration occur in atherosclerosis, restenosis and venous graft disease. We studied the effects of $17 \beta$-estradiol on SMC proliferation and migration. Methods: SMC were cultured from saphenous veins of postmenopausal women and age-matched men. Cell growth was determined by ${ }^{3} \mathrm{H}$-thymidine incorporation and cell counting. Migration of SMC was assessed in 4-well chambers. SMC were seeded in one corner and PDGF-BB in filter paper glued onto the opposite wall. Results: PDGF-BB $(5 \mathrm{ng} / \mathrm{ml}$ for $24 \mathrm{~h})$ similarly stimulated ${ }^{3} \mathrm{H}$-thymidine incorporation in female $(511 \pm 57 \% ; n=8)$ and male $(528 \pm 62 \% ; n=12)$ SMC. This was reduced by $17 \beta$-estradiol $\left(10^{-8}-10^{-6} \mathrm{M}\right.$; female $313 \pm 52 \%$; male $337 \pm 54 \%$; $P<0.05)$. PDGF-BB increased the number of SMC $(P<0.0001$ at 10 days) obtained from females $(153 \pm 3 \% ; n=5)$ and males $(150 \pm 4 \% ; n=5)$, which was inhibited by $17 \beta$-estradiol $\left(10^{-6} \mathrm{M}\right.$; female $134 \pm 7 \%$; male $128 \pm 5 \%$; $\left.P<0.05\right)$. Similar results were obtained with basic fibroblast growth factor. In contrast to $17 \beta$-estradiol, another steroid (dexamethasone) had no effects on ${ }^{3} \mathrm{H}$-thymidine incorporation in these cells stimulated with PDGF-BB. PDGF-BB $(0.01-1 \mathrm{ng})$ stimulated SMC migration $(P<0.05)$ which was inhibited by $17 \beta$-estradiol $\left(10^{-10}-10^{-6} \mathrm{M} ; n=5 ; P<0.005\right)$. Conclusion: $17 \beta$-Estradiol inhibits growth-factor-induced SMC proliferation and migration regardless of gender. These effects of $17 \beta$-estradiol may contribute to its cardiovascular protective properties in postmenopausal women during replacement therapy.
\end{abstract}

Keywords: FGF; Estrogen; PDGF; Human, saphenous vein

\section{Introduction}

Coronary artery disease is the leading cause of death in industrialized countries. Percutaneous transluminal coronary angioplasty (PTCA) and bypass surgery are wellestablished methods of treating these patients $[1,2]$. How-

\footnotetext{
" Corresponding author. Tel.: (+41-31) 6329653 (pager 181-6050), (+41-31) 63296 52; fax: (+41-31) 3821069 .

${ }^{1}$ Present address: Istituto Di Patologia Medica, Università degli Studi di Ancona. Ospedale Umberto I, Piazza Cappeli 1, I-60100 Ancona, Italy.

${ }^{2}$ Present address: Department of Nephrology and Hypertension, University Hospital Utrecht, Utrecht, Netherlands.
}

ever, both procedures do not prevent progression of the disease. Furthermore, PTCA is associated with restenosis and bypass surgery with graft disease, particularly venous graft disease [1,2]. Cell proliferation and migration are believed to be critical for accumulation of smooth muscle cells (SMC) in the intima, and this may be important for vascular luminal narrowing [3,4]. Platelet-derived growth factor (PDGF) and basic fibroblast growth factor (bFGF) released from platelets and activated vascular cells are considered to be important in triggering SMC proliferation and migration $[3,4]$.

Time for primary review 27 days. 
The incidence of coronary artery disease in premenopausal women is lower than in men and increases after the menopause [5-7]. Estrogen replacement therapy in postmenopausal women markedly reduces cardiovascular events $[5,8,9]$. Hence, female sex hormones and $17 \beta$-estradiol in particular may protect women against vascular disease [5]. However, the cardiovascular protective effects of estrogens remain unclear, althought it has been documented that they inhibit vasoconstriction in an endothelium-dependent as well as endothelium-independent manner [10-14]. Furthermore, estrogens favorably change the lipid metabolic profile $[5,15]$. More recent studies on the rat aorta and human coronary artery circulation demonstrated gender differences in endothelial function modulating vascular tone $[16,17]$. This study was designed to investigate whether a gender difference concerning the effects of $17 \beta$-estradiol on SMC proliferation and migration exists in cells obtained from postmenopausal women and age-matched men.

\section{Methods}

\subsection{Materials}

Bovine serum albumin, 17 $\beta$-estradiol, dexamethasone, monoclonal antibody against $\alpha$-smooth muscle actin and cytosine- $\beta$-D-arabinofuranoside were obtained from Sigma (Buchs, Switzerland), recombinant platelet-derived growth factor-BB, basic fibroblast growth factor, fibronectin, agarose and all tissue culture materials were obtained from Gibco (Basel, Switzerland). ${ }^{3} \mathrm{H}$-Methylthymidine was from Amersham (Zürich, Switzerland), trichloroacetic acid from Fluka (Buchs, Switzerland), and blotting paper (GB004) from Schleicher and Schuell (Feldbach, Switzerland).

\subsection{Isolation and cultivation of cells}

Vascular SMC were isolated from saphenous veins of 8 postmenopausal women without estrogen replacement therapy (mean age 65 years, range 57-72) and 12 age-matched men (mean age 62 years, range $55-71$; n.s.) undergoing coronary bypass surgery by explant technique as described previously [18]. Vascular SMC were cultured in phenol red-free Dulbecco's Modified Eagle Medium (DMEM) containing $20 \%$ fetal calf serum (FCS) supplemented with $2 \mathrm{mM}$ L-glutamine and $10 \mathrm{mM}$ HEPES buffer solution, $100 \mathrm{U} / \mathrm{ml}$ penicillin and $100 \mu \mathrm{g} / \mathrm{ml}$ streptomycin in a humidified atmosphere $\left(37^{\circ} \mathrm{C} ; 95 \%\right.$ air $\left./ 5 \% \mathrm{CO}_{2}\right)$. In certain experiments, cells were grown in culture medium containing phenol red. Culture medium was replaced every 3 days. Cells were passaged by trypsinization $(0.05 \%$ trypsin-EDTA). Experiments were performed between passages 3 and 6. SMC were characterized by indirect immunofluorescence staining using specific anti-smoothmuscle $\alpha$-actin antibodies $[18,19]$.

\subsection{Asscy of cell mitogenicity}

Cells were seeded on 12-well plates (density: $10^{4} / \mathrm{ml}$ for $24 \mathrm{~h}$ to allow attachment). Culture media were then replaced with phenol-red-free, serum-free DMEM medium containing all ingredients as described above and $0.2 \%$ bovine serum albumin (BSA) instead of FCS. Cells in serum-free DMEM medium were incubated with or without $17 \beta$-estradiol $\left(10^{-8}-10^{-5} \mathrm{M}\right)$ for $48 \mathrm{~h}$ before stimulation with PDGF-BB $(5 \mathrm{ng} / \mathrm{ml})$ or bFGF $(5 \mathrm{ng} / \mathrm{ml})$. ${ }^{3} \mathrm{H}$-Thymidine incorporation was assayed as described previously $[18,19]$. Incorporated radioactivity was measured with a $\beta$-counter (ICN, Intertechnique, France). In parallel experiments, cell number was counted. Quiescent SMC were treated with or without $17 \beta$-estradiol $\left(10^{-6} \mathrm{M}\right)$ or vehicle (2-hydroxypropyl- $\beta$-cyclodextrin) for $48 \mathrm{~h}$ and then stimulated with PDGF-BB $(5 \mathrm{ng} / \mathrm{ml})$ every 2 days with or without $17 \beta$-estradiol $\left(10^{-6} \mathrm{M}\right)$. Cell number was counted at day 10 (Coulter counter; England).

\subsection{Migration of smooth muscle cells}

Migration assays were performed in 4-well chambers coated with fibronectin $(5 \mu \mathrm{g} / \mathrm{ml})$. VSMC $3 \times 10^{5}$ in 100 $\mu l$ DMEM without phenol red supplemented with $20 \%$ FCS were seeded in one corner of the chambers and incubated overnight to allow for cell attachment. The cells were then washed 3 times with serum-free medium (containing $0.2 \% \mathrm{BSA}$ ) and a start line was drawn along the edge of the attached cells. On the opposite side of the chamber, an $8-\mathrm{mm}^{2}$ filter paper preincubated in $0.1 \%$ agarose containing PDGF-BB (0.01-1 ng/filter) was glued onto the opposite wall of the chambers by using preheated $\left(50^{\circ} \mathrm{C}\right) 0.5 \%$ agarose. $800 \mu \mathrm{l}$ serum-free medium supplemented with $50 \mathrm{mM}$ cytosine- $\beta$-D-arabinofuranoside were added to each chamber. The cells were incubated for another $48 \mathrm{~h}$ and at the end of the migration assay the cells were then washed with PBS, fixed with $4 \%$ paraformaldehyde, and stained with hematoxylin. The migration of VSMC was assessed by blinded counting of the number of cells observed across the start line using light microscopy. To investigate possible inhibitory effects of $17 \beta$-estradiol on PDGF-BB-induced VSMC migration, the cells were pretreated with $17 \beta$-estradiol for $24 \mathrm{~h}$. The migration assays were then performed with PDGF-BB at the optimal stimulatory dose ( $1 \mathrm{ng} /$ filter).

\subsection{Statistical analysis}

All experiments were performed in triplicate. Data are presented as percent of control and given as means \pm s.e.m. One-way factorial analysis of variance (ANOVA) was used for statistical analysis. $n$ equals number of patients. A two-tailed $P$-value smaller than 0.05 was considered significant. 


\section{Results}

\subsection{Effects of estrogen on cell proliferation}

PDGF-BB ( 0.01 to $10 \mathrm{ng} / \mathrm{ml})$ concentration-dependently stimulated ${ }^{3} \mathrm{H}$-thymidine incorporation which reached a maximum at $5 \mathrm{ng} / \mathrm{ml}$. PDGF-BB $(5 \mathrm{ng} / \mathrm{ml})$ increased ${ }^{3} \mathrm{H}$-thymidine incorporation into vascular smooth muscle cells obtained from postmenopausal women (511 $\pm 57 \%$ above control; Fig. 1 left; $n=8 ; P<0.0001$ versus control) and by $528 \pm 62 \%$ in cells obtained from age-matched men (Fig. 1 right; $n=12 ; P<0.0001$ versus control). 17ß-Estradiol $\left(10^{-8}-10^{-6} \mathrm{M}\right)$ reduced ${ }^{3} \mathrm{H}$ thymidine incorporation into vascular smooth muscle cells from postmenopausal women to $313 \pm 52 \%(n=8 ; P<$ 0.05 versus PDGF-BB alone) and to a similar degree also in those obtained from men ( $337 \pm 54 \% ; n=12 ; P<0.05$ versus PDGF-BB alone). The vehicle, 2-hydroxypropyl$\beta$-cyclodextrin, had no effects on PDGF-BB-stimulated cell proliferation. If vascular smooth muscle cells were cultured in medium containing phenol red, no inhibitory effect of 17ß-estradiol on PDGF-BB-induced ${ }^{3} \mathrm{H}$-thymidine incorporation was observed. After 10 days of stimulation with PDGF-BB $(5 \mathrm{ng} / \mathrm{ml})$, the number of vascular smooth muscle cells obtained from women (Fig. 2, left; $153 \pm 3 \%, n=5 ; P<0.0001$ versus control) as well as from men was increased (Fig. 2, right; $150 \pm 4 \%, n=5$; $P<0.0001$ versus control). $17 \beta$-Estradiol $\left(10^{-6} \mathrm{M}\right)$ reduced cell numbers in female cells $(134 \pm 7 \%, n=5$; $P<0.05$ versus PDGF-BB alone) as well as in male cells $(128 \pm 5 \% ; n=5 ; P<0.05$ versus PDGF-BB alone), while the hormone alone did not change the cell number (Fig. 2; n.s. versus control).

In contrast to $17 \beta$-estradiol, dexamethasone $\left(10^{-9}-10^{-6}\right.$ M), also a steroid, had no effects on ${ }^{3} \mathrm{H}$-thymidine incor-

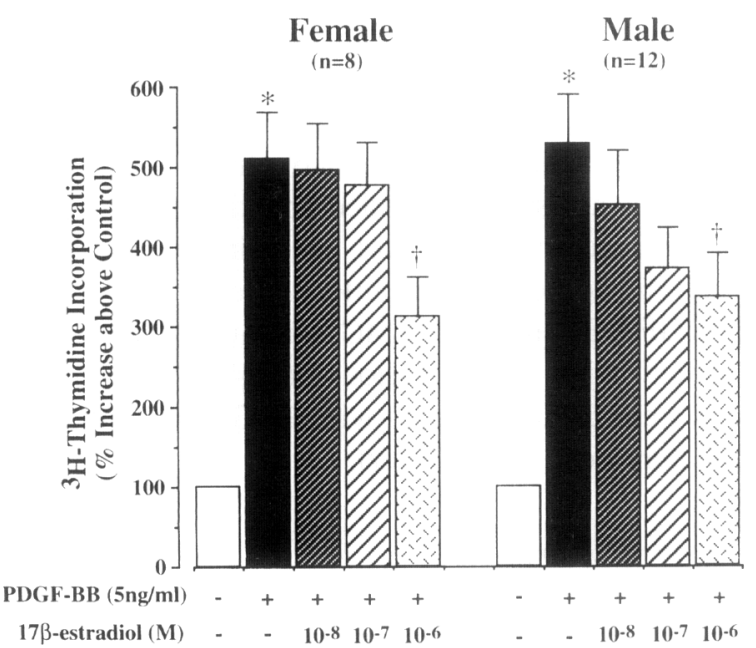

Fig. 1. Effects of $17 \beta$-estradiol on DNA synthesis stimulated by PDGF-BB in vascular smooth muscle cells of female (left panel) and male patients (right panel). PDGF-BB stimulated ${ }^{3} \mathrm{H}$-thymidine incorporation after 24 h; 17ß-estradiol reduced this effect. Data are shown as mean \pm s.e.m. ( $n$ $=$ number of patients). ${ }^{*} P<0.0001$ vs. control; $\nmid P<0.05$ vs. PDGFBB alone.

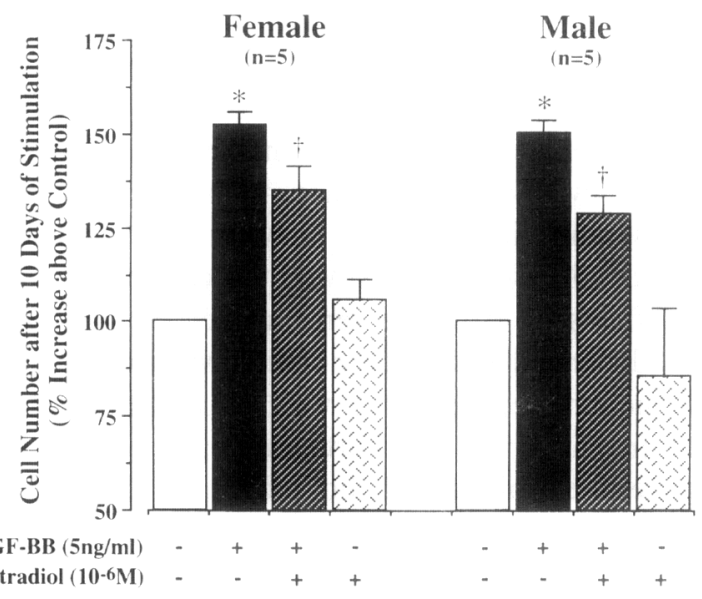

Fig. 2. Effects of $17 \beta$-estradiol on increase in cell numbers stimulated by PDGF-BB in human vascular smooth muscle cells of female (left panel) and male patients (right panel). PDGF-BB increased cell number after 10 days of stimulation, which was reduced by $17 \beta$-estradiol $\left(10^{-6} \mathrm{M}\right)$, while the hormone alone had no effect. Data are shown as mean \pm s.e.m. $(n=$ number of patients). ${ }^{*} P<0.0001$ vs. control; $\uparrow P<0.05$ vs. PDGF-BB alone.

poration into cells stimulated with PDGF-BB $(5 \mathrm{ng} / \mathrm{ml}$; Fig. 3; $n=15,8$ males and 7 females).

Similar results to those with PDGF were obtained in cells stimulated with bFGF, where $17 \beta$-estradiol also inhibited the effects of the growth factor on ${ }^{3} \mathrm{H}$-thymidine incorporation $(n=9,4$ females and 5 males; $P<0.05$, Fig. 4 right). Heparin $(0.1-100 \mu \mathrm{g} / \mathrm{ml})$, however, exhibited a more pronounced inhibitory effect on ${ }^{3} \mathrm{H}$-thymidine incorporation stimulated with bFGF $(5 \mathrm{ng} / \mathrm{ml})$ in the smooth muscle cells $(n=5,3$ females and 2 males; $P<$ 0.05 , Fig. 4 left).

\subsection{Effects of estrogen on cell migration}

PDGF-BB (0.01-10 ng/filter) induced a dose-dependent increase in the migration of human saphenous vein

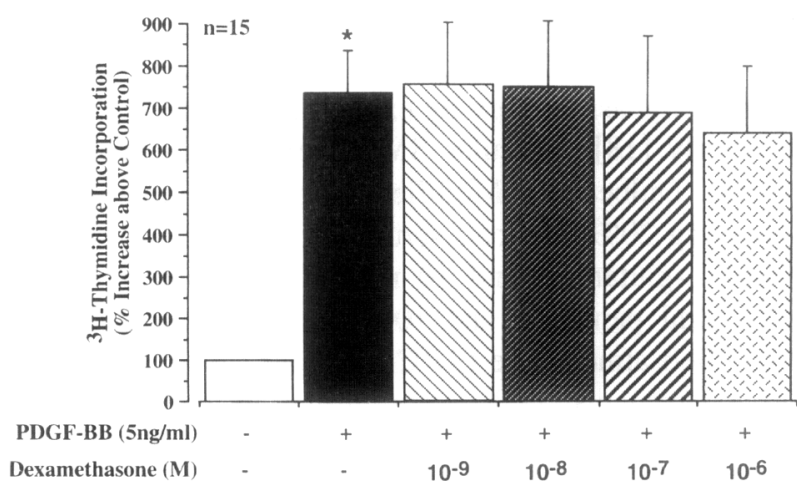

Fig. 3. Effects of dexamethasone on DNA synthesis stimulated by PDGF-BB in vascular smooth muscle cells. Preincubation of the cells with the steroid dexamethasone for $48 \mathrm{~h}$ had no effects on PDGF-BB stimulated ${ }^{3} \mathrm{H}$-thymidine incorporation after $24 \mathrm{~h}$. Data are shown as mean \pm s.e.m. ( $n=$ number of patients). ${ }^{*} P<0.001$ vs. control. 

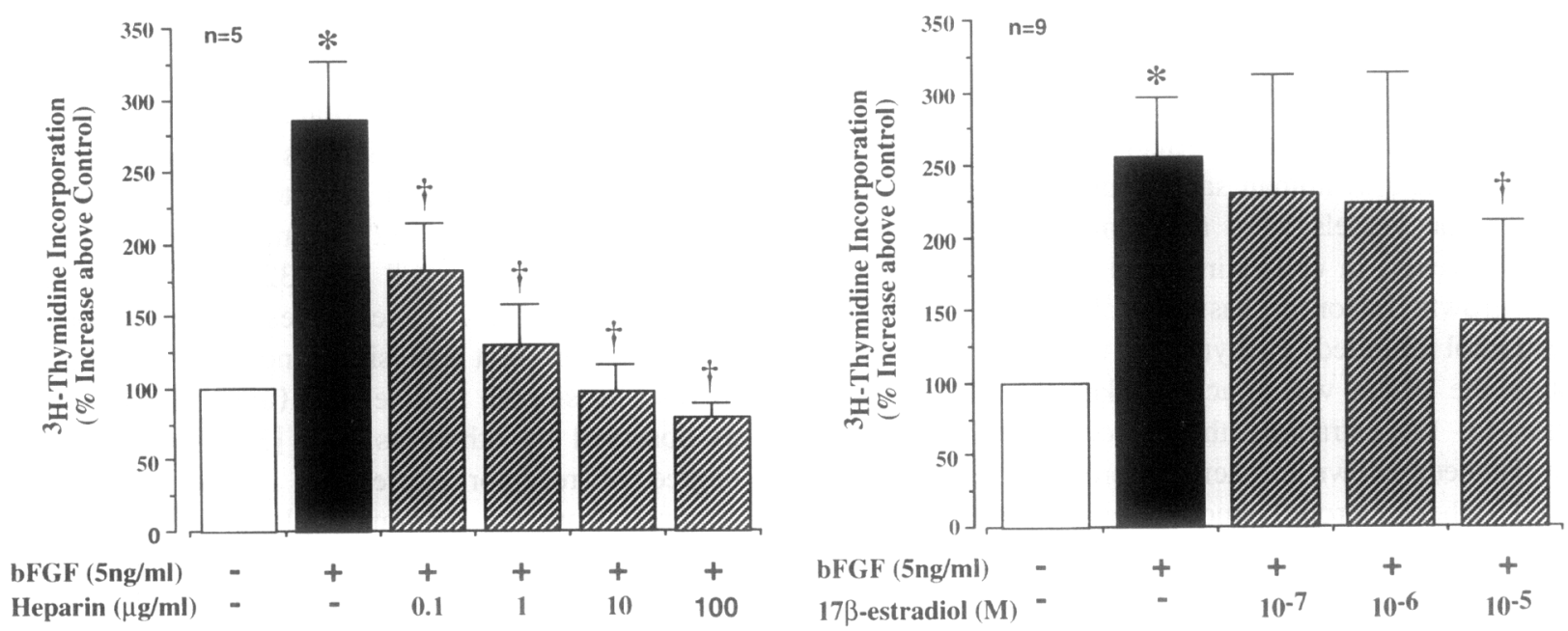

Fig. 4. Comparision of the effects of heparin (left panel) and 17ß-estradiol (right panel) on DNA synthesis stimulated by bFGF in human vascular smooth muscle cells. Note that bFGF potently stimulated ${ }^{3} \mathrm{H}$-thymidine incorporation which was abolished by heparin (left panel; $n=5, P<00.5$ ) and reduced by 173-estradiol (right panel; $n=9 ; P<0.05$ ). ${ }^{*} P<0.05$ vs. control; $\dagger P<0.05$ vs. PDGF-BB alone.

smooth muscle cells (Fig. 5A). The maximal effect occurred at $1 \mathrm{ng}$ of PDGF-BB, where migration was stimulated more than 5 -fold over control $(P<0.05 ; n=4,3$ males and 1 female).

Prior incubation of smooth muscle cells with $17 \beta$ estradiol $\left(10^{-10}-10^{-6} \mathrm{M}\right)$ concentration-dependently in-

A

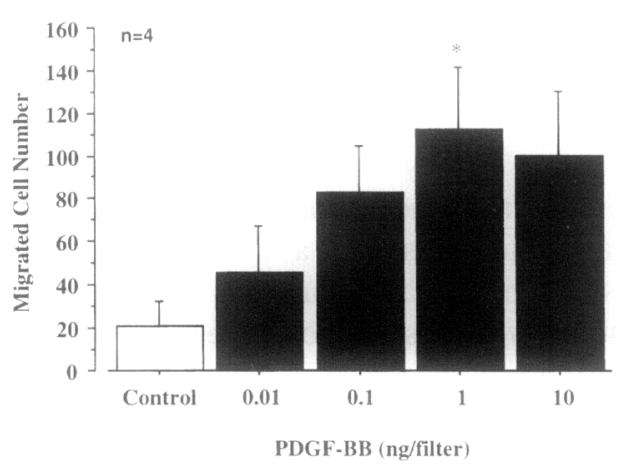

B

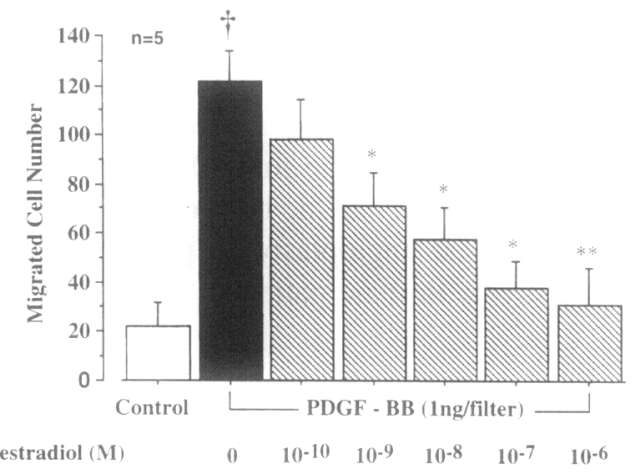

Fig. 5. Stimulation of migration of human sapheneous vein SMC in culture by PDGF-BB. PDGF-BB (0.01-10 ng/filter) induced a dose-dependent migration of the cells (top panel; $n=4,{ }^{*} P<0.05$ vs. control). In cells pretreated with $17 \beta$-estradiol $\left(10^{-10}-10^{-6} \mathrm{M}\right)$ these effects of PDGF-BB were concentration-dependently inhibited by $17 \beta$-estradiol (lower panel; $n=5, \dagger P<0.05$ vs. control; ${ }^{*, *} P<0.05$ to 0.005 vs. PDGF-BB alone). hibited PDGF-sinduced migration (Fig. 5B). The number of migrated smooth muscle cells was reduced at $10^{-9} \mathrm{M}$ of $17 \beta$-estradiol $(P<0.05)$ and was maximal $(P<0.005$; $n=5,3$ males and 2 females) at $10^{-6} \mathrm{M}$ as compared with PDGF-BB alone.

\section{Discussion}

This study demonstrates that $17 \beta$-estradiol inhibits proliferation and migration of human vascular smooth muscle cells of saphenous veins stimulated by mitogens such as platelet-derived growth factor and basic fibroblast growth factor. Most interestingly, these antiproliferative and antimigratory effects of $17 \beta$-estradiol occurred in vascular smooth muscle cells obtained from postmenopausal women as well as from age-matched men with coronary artery disease.

Protective effects of estrogens against cardiovascular disease in postmenopausal women are well documented [5]. Putative mechanisms may involve endothelium-dependent and -independent vasodilation [10-14] and an improved lipid profile $[5,15]$. Furthermore, estrogen stimulates endothelial nitric oxide synthase activity in vivo [20], and may inhibit smooth muscle cell proliferation via endothelium-derived nitric oxide [21]. Proliferation and migration of vascular smooth muscle cells are believed to contribute significantly to intimal thickening in atherosclerosis, restenosis and venous bypass graft disease $[2,3]$. Experiments with cultured vascular smooth muscle cells obtained from rats and pigs, however, revealed inconsistent antiproliferative effects of $17 \beta$-estradiol [22,23], suggesting important species differences or vessel differences. This study provides the first evidence that $17 \beta$-estradiol inhibits smooth muscle cell proliferation in postmenopausal women and also in men with coronary artery 
disease. In unstimulated cultured human vascular smooth muscle cells, $17 \beta$-estradiol alone exerted no significant effects in line with the observation by Calcagno et al. who did not find antiproliferative effects of estrogen on ${ }^{3} \mathrm{H}$ thymidine uptake in human saphenous vein organ culture [24] when the vessels were not stimulated with growth factors. However, in cells stimulated with either plateletderived growth factor or basic fibroblast growth factor, $17 \beta$-estradiol inhibited ${ }^{3} \mathrm{H}$-thymidine uptake of these cells, although the effect was much weaker than heparin. In contrast to 17ß-estradiol, the steroid, dexamethasone, which has been shown to exert antiproliferative effects in diseased (atherosclerotic) smooth muscle cells [25] and inhibits intimal thickening in rat carotid artery after balloon injury [26], had no effects on DNA synthesis in these venous smooth muscle cells. The different observations between the present study and those previous studies may be due to the different cell types and species used. In addition, 17 $\beta$-estradiol reduced the increase in cell numbers evoked by platelet-derived growth factor. These results, therefore, indicate that $17 \beta$-estradiol specifically interferes with the effects of growth factors in vascular smooth muscle cells. The fact that the antiproliferative effects of $17 \beta$-estradiol were comparable in cells obtained from postmenopausal women to those from age-matched men indicates that vascular smooth muscle can respond to $17 \beta$-estradiol regardless of gender, at least at this age stage. Whether smooth muscle cells from premenopausal women have similar behavior remains unclear. The concentrations used in the present study to inhibit cell proliferation are beyond the physiological range in vivo, but are the same as those used in other studies which demonstrated acute effects of the hormone on the blood vessel wall $[17,27]$. It is conceivable, however, that with prolonged exposure to estrogens similar effects on blood vessel wall may occur even at physiological concentrations.

In addition to proliferation, migration of vascular smooth muscle cells contributes significantly to vascular structural changes occurring in atherosclerosis, restenosis and venous graft disease $[3,4,28-30]$. In this study, $17 \beta$-estradiol was most effective in inhibiting migration of human vascular smooth muscle cells induced by platelet-derived growth factor. It has been discussed that migration of smooth muscle cells from the media into the intima accounts in large part for the accumulation of this cell type in atherosclerotic as well as intimal hyperplasia occurring after balloon injury [4,28-30]. The evolving concept of vascular remodeling [4] may also involve considerably the migratory responses of smooth muscle cells of the media.

The cellular mechanisms of the antiproliferative and antimigratory effects of $17 \beta$-estradiol may involve several pathways. The classical pathway utilized by $17 \beta$-estradiol and related steroids involves activation of the estrogen receptor [31]. This receptor is located intracellularly and is translocated into the nucleus after binding of its specific ligand [31]. RT-PCR demonstrated mRNA expression of estrogen receptors in vascular smooth muscle cells of both female and male patients (data not shown). This is in agreement with previous studies and further for the first time demonstrates that the receptor is expressed regardless of the gender of cells [32]. Compared to MCF-7 cells, a mammary carcinoma cell line [32], and human umbilical vein endothelial cells, the expression levels were lower. Also, Northern blot analysis did not reveal a reliable signal in vascular smooth muscle cells (unpublished observation) as observed by others as well [32], suggesting that the degree of receptor expression is lower than in tissue obtained from the mammary gland or sexual organs or endothelial cells. Phenol red interferes with estrogen receptors [33] and in this study prevented the inhibitory effects of $17 \beta$-estradiol on proliferation induced by platelet-derived growth factor. However, it is still unclear whether the estrogen receptor mediates these effects of the hormone in these particular cells, since estrogens also bind to membrane-associated binding sites [34] and three splicing variants of estrogen receptors in addition to the wild type of the receptor have been identified in rat vascular smooth muscle cells by a recent study [35].

Antiproliferative and antimigratory effects of estrogen in vascular smooth muscle cells may contribute to a lower incidence of cardiovascular disease in premenopausal women than in age-matched men [9]. In addition, these effects may - together with the effects of estrogens on risk factors [36] and endothelial cells [37] _ account for the reduction of cardiovascular events seen with hormone replacement therapy in postmenopausal women [5,9]. Interestingly, in premenopausal women with atherosclerotic coronary artery disease, a decreased estrogen receptor expression in the vasculature has been demonstrated [38]. This strongly suggests a protective role of estrogens against coronary artery disease in women and a role of estrogen receptor expression in the development of the disease. Our study further raises the posssibility that males also would benefit from stimulation of the estrogen receptors in vascular smooth muscle; however, the side-effects of this appoach in other organs such as the testes and breast tissue render the use of this hormone unacceptable for primary or secondary prevention in the male. It is conceivable, however, that local delivery of the hormone (e.g., after percutaneous transluminal angioplasty to prevent restenosis [1]) may be used also in male patients.

\section{Acknowledgements}

This study was supported by the Swiss National Research Foundation (No. 32-32541.91), the Swiss Cardiology Foundation, the Schweizerische Mobiliarversicherung, the Ciba-Foundation and Patria Insurance. 


\section{References}

[1] Forrester JS, Fishbein M, Helfant R, Fagin J. A paradigm for restenosis based on cell biology: clues for the development of new preventive therapies. J Am Coll Cardiol 1991;17:752-757.

[2] Lüscher TF, Turina M, Braunwald E. Coronary Artery Graft Disease: mechanisms and prevention. Heildelberg-New York: Springer Publishers, 1994.

[3] Ross R. The pathogenesis of atherosclerosis - an update. N Engl J Med 1986;314:488-500.

[4] Schwartz SM, DeBlois D, O'Brien ER.M. The intima: soil for atherosclerosis and restenosis. Circ Res 1995;77:445-465.

[5] Belchetz PE. Hormonal treatment of postmenopausal women. N Engl J Med 1994;330:1062-1071.

[6] Colditz GA, Willett WC, Stampfer MJ, Rosner B, Speizer FE, Hennekens $\mathrm{CH}$. Menopause and the risk of coronary heart disease in women. N Engl J Med 1987;316:1105-1110.

[7] NIH. Chartbook on Cardiovascular, Lung and Blood Diseases. Washington, DC: US Department of Health and Human Services, May 1992.

[8] Gruchow HW, Anderson AJ, Barboriak JJ, Sobocinski KA. Postmenopausal use of estrogen and occlusion of coronary arteries. Am Heart J 1988;115:954-963.

[9] Stampfer MJ, Colditz GA, Willett WC, et al. Postmenopausal estrogen therapy and cardiovascular disease: ten-year follow-up from the Nurses' health study. N Engl J Med 1991;325:756-762.

[10] Gilligan DM, Badar DM, Panza JA, Quyyumi AA, Cannon RO. Acute vascular effects of estrogen in postmenopausal women. Circulation 1994;90:786-791.

[11] Jiang C, Sarrel PM, Lindsay DC, Poole-Wilson PA, Collins P. Endothelium-independent relaxation of rabbit coronary artery by 173-oestradiol in vitro. Br J Pharmacol 1991;104: 1033-1037.

[12] Williams JK, Adams MR, Klopfenstein HS. Estrogen modulates responses of atherosclerotic coronary arteries. Circ Res 1990;81:1680-1687.

[13] Williams JK, Adams MR, Herrington DM, Clarkson TB. Short-term administration of estrogen and vascular responses of atherosclerotic coronary arteries. J Am Coll Cardiol 1992;20:452-457.

[14] Rosano GM.C, Sarrel PM, Poole-Wilson PA, Collins P. Beneficial effects of oestrogen on exercise-induced myocardial ischaemia in women with coronary artery disease. Lancet 1993;342:133-136.

[15] Walsh BW, Schiff I, Rosner B, Greenberg L, Ravnikar V, Sachs FM. Effects of postmenopausal estrogen replacement on the concentration and metabolism of plasma lipoproteins. $N$ Engl J Med 1991;325:1196-1240.

[16] Stallone JN. Role of endothelium in sexual dimorphism in vasopressin-induced contraction of rat aorta. Am J Physiol 1993;265:H2073-H2080.

[17] Collins P, Rosano GMC, Sarrel PM, et al. 17ß-Estradiol attenuates acetylcholine-induced coronary arterial constriction in women but not men with coronary heart disease. Circulation 1995;92:24-30.

[18] Predel HG, Yang Z, Von Segesser L, Turina M, Bühler FR, Lüscher TF. Implications of pulsatile stretch on growth of sapheneous vein and mammary artery smooth muscle. Lancet 1992;340:878-879.

[19] Yang Z, Noll G, Lüscher TF. Calcium antagonists differently inhibit proliferation of human coronary smooth muscle cells in response to pulsatile stretch and platelet-derived growth factor. Circulation 1993;88:832-836.

[20] Weiner CP, Lzasoain I, Baylis SA, Knowles RG, Charles IG,
Moncada S. Induction of calcium-dependent nitric oxide synthases by sex hormones. Proc Natl Acad Sci USA 1994;91:5212-5216.

[21] Garg UC, Hassid A. Nitric oxide generating vasodilators and 8bromo-cyclic guanosine monophosphate inhibit mitogenesis and proliferation of cultured rat vascular smooth muscle cells. J Clin Invest 1989;83:1774-1777.

[22] Vargas R, Wroblewska B, Rego A, Hatch J, Ramwell PW. Oestradiol inhibits smooth muscle cell proliferation of pig coronary artery. Br J Pharmacol 1993; 109:612-617.

[23] Farhat MY, Vargas R, Dingaan B, Ramwell PW. In vitro effect of oestradiol on thymidine uptake in pulmonary vascular smooth muscle cell: role of the endothelium. Br J Pharmacol 1992;107:683-697.

[24] Calcagno D, Bei M, Ross SA, Klein A, Foegh ML. Effects of estrogen on vein grafts. J Cardiovasc Surg 1992;33:579-584.

[25] Voisard R, Seitzer U, Bauer $R$, et al. Corticosteroid agents inhibit proliferation of smooth muscle cells from human atherosclerotic arteries in vitro. Int J Cardiol 1994:43:257-267.

[26] Villa AE, Guzman LA, Chen W, Golomb G, Levi RJ, Topol EJ. Local delivery of dexamethasone for prevention of neointimal proliferation in a rat model of balloon angioplasty. J Clin Invest 1994;93:1243-1249.

[27] Magness RR, Rosenfeld CR. Local and systemic estradiol 17 beta: effects on uterine and systemic vasodilation. Am J Physiol 1989;256:E536-E542.

[28] Ferns GA.A, Raines EW, Sprugel KH, Motani AS, Reidy MA, Ross $R$. Inhibition of neointimal smooth muscle accumulation after angioplasty by an antibody to PDGF. Science 1991;253:1129-1132.

[29] Dubey R, Lüscher TF. Nitric oxide inhibits angiotensin II induced migration of rat aortic smooth muscle cells. J Clin Invest 1995;96:141-149.

[30] Jang IK, Fuster V. Mechanisms of plaque formation and occlusion in venous coronary bypass grafts. Lüscher TF, Turina $M$, Braunwald E, eds. Coronary Artery Graft Disease: Mechanisms and Prevention. Berlin: Springer-Verlag 1994:42-50.

[31] Carson-Jurica MA, Schrader WT, O'Malley BW. Steroid receptor family: structure and functions. Endocrinol Rev 1990;11.201-220.

[32] Karas RH, Patterson BL, Mendelsohn ME. Human vascular smooth muscle cells contain functional estrogen receptor. Circulation 1994;89: 1943-1950.

[33] Berthois Y, Katzenellenbogen JA, Katzenellenbogen BS. Phenol red in tissue culture media is a weak estrogen: implications conceming the study of estrogen-responsive cells in culture. Proc Natl Acad Sci USA 1986;83:2496-2500.

[34] Gray WG.N, Biswas EE, Bashirelahi N, Biswas SB. A low-affinity estrogen-binding site in pregnant rat uteri: analysis and partial purification. Proc Natl Acad Sci USA 1994;91:11502-11506.

[35] Inoue S, Hoshino S-J, Miyoshi H, et al. Identification of a novel isoform of estrogen receptor, a potential inhibitor of estrogen action, in vascular smooth muscle cells. Biochem Biophy Res Commun 1996;219:766-772.

[36] Gerhard M, Ganz P. How do we explain the clinical benefits of estrogen? From bedside to bench. Circulation 1995;92:5-8.

[37] Morales DE, McGowan KA, Grant DS, et al. Estrogen promotes angiogenic activity in human umbilical vein endothelial cells in vitro and in a murine model. Circulation 1995;91:755-763.

[38] Losordo DW, Kearney M, Kim EA, Jekanowski J, Isner JM. Variable expression of the estrogen receptor in normal and atheroclerotic coronary arteries of premenopausal women. Circulation 1994;89:1501-1510. 